MARTA CHECHŁOWSKA-LIPIŃŚKA

Uniwersytet Mikołaja Kopernika

\title{
Wróg spod znaku dżihadu - obraz islamu w pracach Oriany Fallaci
}

$\mathrm{O}$ riana Fallaci ${ }^{1}$ to jedna $\mathrm{z}$ bardziej kontrowersyjnych postaci początku XXI wieku. Dziennikarka i pisarka (chociaż sama uważa się za pisarkę i historyka), weteranka wielu wojen, zasłynęła z agresywnych i pełnych pasji wywiadów ze światowymi przywódcami - od ajatollaha Chomeiniego po Lecha Wałęsę. Do jej najsłynniejszych prac z wcześniejszej twórczości należą: „List do nie narodzonego dziecka”, oparty na własnym doświadczeniu niechcianej ciąży, książka „Un Uomo: Romanzo”, poświęcona największej miłości jej życia, zamordowanemu greckiemu rewolucjoniście Alekosowi Panagoulisowi, oraz książka „Inszallah”, której akcja toczy się podczas wojny domowej w Libanie.

Po latach milczenia włoska pisarka ogłosiła na łamach „Corriere della Sera" artykuł, w którym atakuje islam i nawołuje do obrony zachodniej cywilizacji. Ukazał się on 29 września 2001 r. i był odpowiedzią na wydarzenia 11 wrześnie w Stanach Zjednoczonych. Dał on podstawy do pierwszej pracy poświęconej kwestiom współczesnego islamu, czyli „Wściekłość i duma”. Swój dość spektakularny powrót do dyskursu naukowego sama Fallaci tłumaczy tak: „Są jednak chwile w Życiu, gdy milczenie staje się grzechem, a mówienie jest nakazem. Obywatelskim obowiązkiem, moralnym wyzwaniem, imperatywem kategorycznym, przed którym nie ma

Oriana Fallaci (ur. 29 czerwca 1929 we Florencji, zm. 15 września 2006 również we Florencji). 
ucieczki”" W tak dramatycznym momencie, nie tylko dla Stanów Zjednoczonych, ale i całego świata, gdy śmierć poniosło tyle osób, autorka nie wiedziała co może zrobić. Dlatego zdecydowała się robić to, co potrafi najlepiej, czyli pisać. Swój przekaz dla współczesnej Europy i zachodniej cywilizacji kontynuowała w następnych książkach: „Siła rozumu” i „Wywiad z sobą samą. Apokalipsa”. To właśnie te trzy prace opisują i analizują islam, który dla Fallaci jest wielkim zagrożeniem dla chrześcijańskiego Starego Kontynentu. Otwarcie, bez ogródek, przedstawia apokaliptyczną wizję Europy, która dzieje się na jej oczach.

„New York Post” nazwał Fallaci „wyjątkiem w epoce, w której uczciwość i moralna jednoznaczność nie są już uważane za szlachetne cnoty" ${ }^{3}$. Najradykalniejsi krytycy porównywali jej prace do „Mein Kampf”. Opinie o niej i jej twórczości są różne. Jedni ją chwalą i uwielbiają, inni krytykują i oskarżają o rasizm, propagowanie wrogości wobec Arabów ${ }^{4}$. Również krytycy są podzieleni co do wartości artystycznej jej prac. Na pewno jednak wywołała sporo zamieszania we współczesnym świecie swoimi oryginalnymi poglądami i warto je omówić.

Oriana Fallaci uważa, że płynie pod prąd i odważa się mówić rzeczy, które ze względu na tzw. poprawność polityczną zostały wyrzucone z oficjalnego dyskursu. Jej zdaniem, takim swoistym tabu jest obecnie islam i jego wyznawcy: „Jeśli powiesz, co myślisz o Watykanie, o Kościele Katolickim, o Papieżu, o Matce Boskiej, o Jezusie, o Świętych, nic cię złego nie spotka. Ale jeśli zrobisz to samo z Islamem, z Koranem, z Mahometem, z synami Allacha, będziesz rasistką i ksenofobem, i świętokradcą, i dopuścisz się dyskryminacji rasowej" ${ }^{5}$. Zarzuty te nie są wyolbrzymione, bo sama autorka doświadczyła ich na własnej skórze. Nie wpłynęło to jednak na jej stanowisko i do ostatnich dni życia podtrzymywała swoje poglądy.

\section{Krok po kroku}

We wszystkich pracach Fallaci dokładnie przedstawia powolny proces „przejmowania” Europy przez wyznawców Mahometa. Nie boi się stwierdzić „że Europa jest już prowincją, a nawet kolonią Islamu”. W „Sile

\footnotetext{
O. Fallaci, Wściekłość i duma, Warszawa 2003, s. 15.

O. Fallaci, Siła rozumu, Warszawa 2004, s. 15.

25 maja 2005 sędzia śledczy we Włoszech zdecydował o ściganiu Oriany Fallaci za obrazę islamu po wniesieniu przeciwko niej pozwu przez przewodniczącego Związku Muzułmanów Włoch Adela Smitha, http://pl.wikipedia.org/wiki/Oriana_Fallaci

o. Fallaci, Sita rozumu, s. 30 .

Ibidem, s. 37.
} 
rozumu" opisuje ona XVII-wieczną inwazję Islamu na Europę i stwierdza, że obecna inwazja nie jest niczym innym, jak tylko odmiennym obliczem tamtego ekspansjonizmu, jednak bardziej podstępnym i bardziej zdradzieckim „Bo jej objawem nie są jedynie bin Ladenowie, Saddamowie Husajnowie, Arafatowie, [...] terroryści, którzy wysadzają się w powietrze w wieżowcach i autobusach. Są nimi także imigranci, którzy sadowią się w naszych domach i bez żadnego poszanowania dla naszych praw narzucają nam swe wartości" ${ }^{\text {, }}$. Najbardziej złowieszczy jest fakt, że współczesna inwazja nie toczy się pod znakiem otwartej wojny i zajęcia siłą, też powolnego zasiedlania centymetr po centymetrze naszych osiedli, miast i państw. Spektakularne ataki zapadają w pamięć i poruszają opinię publiczną, jednak mało kto dostrzega, co dzieje się na co dzień.

Uderzającym przykładem tego powolnego opanowywania jest opisany przez Fallaci wywiad z Abdulem Qadir Fadl Allah Mamour, imamem Carmagnoli - małego miasteczka w Piemoncie. Początkowo jego poglądy i plany poruszają czytelnika, ponieważ jego celem jest założenie muzułmańskiego miasta we Włoszech. Jednak w porównaniu z wystąpieniem jego żony wydają się one wręcz nieistotne. Gdyby nie informacja, że jest to żona wspomnianego imama, matka pięciorga dzieci, Fallaci trudno byłoby rozpoznać co kryje się pod czadorem uzupełnionym przez nikab. Okazało się, że kobieta nazywa się Aisha Farina, nawróciła się na Islam 8 i pół roku temu i jest z Mediolanu. Ta niegdyś Europejka próbuje przekonać, że bin Laden działa na rzecz i z woli świata muzułmańskiego za co wyznawcy Mahometa go kochają, tak jak i ona uważa go za brata - za bohatera. Później „dorzuciła jeszcze, że synowie Allacha chcą nas sobie podporządkować. Podbić nas. I żeby nas podbić, nie muszą obracać w perzynę naszych drapaczy chmur czy naszych zabytków. Wystarczy im nasza słabość i ich płodność..." . Nowy sposób podpijania państwa - wojna demograficzna, jest już dobrze znany i określenie to weszło do ogólnego dyskursu. W ten sposób bardzo łatwo można zdobyć kontrolę nad wielkimi obszarami ziemi. Wiedzą o tym Palestyńczycy, Albańscy mieszkańcy Kosowa, ale także muzułmańscy imigranci w Europie. Aisha Farina także ma tego świadomość i na końcu swojego prostego, wręcz prymitywnego przemówienia, dodaje, że „podbijemy was na drodze pokojowej. Ponieważ w każdym

Ibidem, s. 51.

Ibidem, s. 89-91.

Ibidem, s. 91. 
pokoleniu przybywa nas dwa razy albo więcej. Was natomiast o połowę ubywa" ${ }^{10}$.

Jak bardzo niebezpieczny jest islam uświadomił Fallaci wywiad z George'em Habaszem, czyli przywódcą Ludowego Frontu Wyzwolenia Palestyny, któremu we wczesnych latach 70. zawdzięczaliśmy większość zamachów w Europie. Uświadomił on autorce, że wrogiem Arabów nie jest jedynie Izrael, jest nim także Ameryka, Europa, Zachód. Oto co powiedział: „Nasza rewolucja to moment w rewolucji światowej. nie ogranicza się do podbicia Palestyny. Należy być szczerym i przyznać, że chcemy doprowadzić do wojny takiej, jak wojna w Wietnamie. [...] Ameryka i Europa muszą wiedzieć, że jesteśmy dopiero na samym początku. [...] Przesuwać się krok po kroku, milimetr po milimetrze. [...] Zdeterminowani, uparci, cierpliwi. Oto nasza strategia. Strategia, którą zresztą rozszerzymy"11. Jednak w tamtym okresie Fallaci pod pojęciem wojny z zachodem rozumiała rzezie, zamachy, wojnę, którą się prowadzi na polu bitwy. Nie dostrzegała, że tą długofalową strategią jest wojna demograficzna, kradzież kraju jego obywatelom. Obecnie niestety już nie tylko muzułmańskie kobiety są tajną bronią islamu, ale również europejski, które wybierają sobie wyznawców Mahometa na mężów i przechodzą na islam.

Rysuje się tutaj obraz ekspansjonistycznego islamu, którego celem jest powolne, ale konsekwentne przejmowanie Europy. Chociaż przywódcy islamscy oficjalnie wypowiadają swoje cele i zamiary, to jednak opinia publiczna je bagatelizuje, nie podaje do publicznej wiadomości. Wszystko robione jest dla spokoju społecznego. Dla Fallaci jest to jednak za wysoka cena. Nie można tak bez walki oddawać swojego miasta, państwa imigrantom.

\section{Brak poszanowania dla wartości}

Autorka uważa, że wszelkie porozumienie z wyznawcami Mahometa jest nie do osiągnięcia, ponieważ nasze kultury nie mają wspólnych wartości, na których możnaby oprzeć dialog. Muzułmanie nie szanują nas, ale co gorsza, nie wyznają zasad, które obowiązują nawet w świecie zwierząt. Dla potwierdzenia swojej tezy, Fallaci opowiada relację o zabójstwie Paula Johnsona, amerykańskie inżyniera. Dokładnie przedstawia jak Johnson płacze, błaga o litość, a jego kat, ubrany w biały fartuch, ze złotym zegarkiem na ręku precyzyjnie, powoli odcina mu głowę. W tle zaś koją-

Ibidem, s. 91.

Ibidem, s. 145. 
cy śpiew kobiety: „Niszczcie ich, niszczcie ich!”12. Głowę Johnsona, jako trofeum, znaleziono później w zamrażalniku jednego z hersztów Al-Kaidy. Na pytanie dlaczego to opowiada mówi: „Żeby Panią przerazić. Przestraszyć, oburzyć. A także, aby zrozumiała Pani, dlaczego ich nienawidzę tak samo, jak oni nienawidzą mnie. Ach! Śmiać mi się chce, kiedy słyszę frazesowiczów deklamujących: >>Terroryzmu nie zwalcza się za pomocą siły ${ }^{" 13}$. Fallaci próbuje pokazać, że muzułmanie nie mają poszanowania dla jakichkolwiek naszych wartości. Ten amerykański inżynier nie był dla swoich oprawców człowiekiem, był mniej warty niż zwierze. Skoro zatem wyznawcy Mahometa nie szanują nas - chrześcijan, to dlaczego my mamy szanować ich? Fallaci tym samym w tolerancji kładzie wielki nacisk na transparentność i wzajemność. Jeśli bowiem muzułmanie chcą, aby cały świat szanował ich tradycję i zwyczaje, muszą szanować inne wyznania. A tak niestety nie jest.

Muzułmanie - zdaniem autorki - nie mają poszanowania dla jakichkolwiek wartości, nie tylko europejskich, ale nawet tych funkcjonujących w świecie zwierząt. Fallaci przedstawia obraz dzieci irańskich, które w latach osiemdziesiątych na granicy z Irakiem chomeiniści wysyłali na zaminowane pole. Miały one przygotowywać przejście dla oddziału ${ }^{14}$. Był to drastyczny widok porozrywanych na kawałki ciał, które rozrzucone były na całej zaminowanej przestrzeni. Co to za kultura, która poświęca niewinne, bezbronne dzieci. Nawet zwierzęta chronią swoje młode. Dlatego Fallaci pozwala sobie na wniosek, że w tej religii nie ma poszanowania dla żadnych wartości. Wielokrotnie Islam porównany jest do Bestii z Apokalipsy według św. Jana. Uderzający jest jednak fakt, że Apokalipsa opisuje koniec świata i sąd ostateczny, czyli dla wielu odległą przyszłość. Autorka uczula, że ta przepowiednia realizuje się teraz, urzeczywistnia się na naszych oczach.

Aby móc nawiązać dialog pomiędzy różnymi wyznaniami, kulturami, konieczna jest pewna wspólna płaszczyzna, od której możnaby wyjść i dyskutować sporne kwestie. Dla Fallaci jasno i wyraźnie widać, że islam nie szanuje chrześcijan, europejskich wartości, ani zasad funkcjonujących w świecie zwierząt, dlatego nie można mówić o żadnym dialogu.

12 O. Fallaci, Wywiad z sobą sama. Apokalipsa, Warszawa 2005, s. 127-128.

13 Ibidem, s. 128-129.

14 O. Fallaci, Wywiad z sobą sama. Apokalipsa, s. 176. 


\section{Brak wzajemności}

Brak wspólnych wartości wiąże się z brakiem wzajemności w relacjach pomiędzy muzułmanami a chrześcijanami i wyznawcami innych wyznań. Jak bardzo nieodwzajemnione jest poszanowanie wartości, a asymilacja to tylko wielkie złudzenie ukazuje opowieść Virgilia, siedemnastolatka z Castelfiorentino, który napisał list do Fallaci. Chłopiec ten ma siostrzyczkę, która chodzi do szkoły podstawowej i babcię, która robi pączki z marsalą, zgodnie z toskańską tradycją (czyli dodając łyżkę wina marsala do ciasta). Jakiś czas temu siostrzyczka Virgilia zaniosła pączki do szkoły i poczęstowała kolegów z klasy, a między nimi był pewien muzułmański chłopiec. Bardzo mu one zasmakowały i po powrocie do domu, już w progu mówi do mamy: „Mamusiu, zrobisz mi pączki z marsalą? Jadłem je dzisiaj w szkole i..." ${ }^{\prime 1}$. Następnego dnia ojciec rzeczonego chłopczyka stawił się u dyrektorki z Koranem w ręku. Powiedział jej, że poczęstowanie jego syna pączkami z likierem było zniewagą wobec Allacha i zażądał wyjaśnień. Oskarżył ją, że to jej wina, bo pozwoliła przynieść do szkoły to bezbożne jadło ${ }^{16}$. Jak jest możliwe, że imigranci z różnych stron świata przyjeżdżają do Europy i wprowadzają swoje zwyczaje nie szanując naszych. Skoro zdecydowali się zamieszkać w obcym kraju powinni liczyć się z tym, że nie każdy zna ich zasady. Oburzenie ojca jest nie do pomyślenia, bo kto ma się integrować: my czy oni?

Niestety ta jednostronność w relacjach widoczna jest również wśród przedstawicieli kościoła katolickiego. Fallaci nie może zrozumieć dlaczego papież przeprasza muzułman i retorycznie pyta: „Powiedz mi Ojcze Święty: czy to prawda, że jakiś czas temu prosiłeś synów Allacha o przebaczenie za wyprawy krzyżowe, które Twoi poprzednicy podjęli, żeby odzyskać Grób Pański? A czy synowie Allacha kiedykolwiek prosili Cie o przebaczenie za to, że zajęli Grób Pański?"17. Nigdy także nie przepraszali za podbicie Półwyspu Iberyjskiego, za zbrodnie popełnione przez Saracenów na brzegach Toskanii itp.

Fallaci stara się pokazać, że wszelkie próby nawiązania dialogu, czy nawet przepraszania, wychodzą tylko zjednej strony - od chrześcijańskiej Europy. To my wręcz zabiegamy o przebaczenie, zrozumienie, a muzułmanie nie dają nic w zamian. Na każdym kroku narzucają nam tylko swoje obyczaje. Nigdy nie jest tak, że wina leży po jednej stronie.

Ibidem, s. 54.

Ibidem.

O. Fallaci, Wściekłość i duma, s. 76. 


\section{Umiarkowany Islam?}

Osoby, które chronią praw i poszanowania zasad wyznawców Mahometa twierdzą, że nie wszyscy muzułmanie są radykalni, nie wszyscy są terrorystami. Istnieje coś takiego jak umiarkowany islam, który jest do pogodzenia z zasadami państwa prawa i zasadami cywilizacji zachodniej. Oriana Fallaci otwarcie mówi, że to złudzenie, coś takiego nie istnieje i przedstawia na ten temat długi wywód ${ }^{18}$. Wszystkie jej książki o islamie pełne są przykładów pozornie umiarkowanych muzułmanów, którzy pomimo przyjęcia obyczajów kraju przyjmującego, w niespodziewanym momencie je łamią. Takim przykładem jest między innymi Mohammed Lhasni, marokański robotnik zatrudniony na podstawie zgodnej z prawem umowy o pracę i ze zgodnym z prawem pozwoleniem na pobyt. Pobił on na śmierć swoją córkę, ponieważ chciała nosić dżinsy, chodzić do kina i widywać się z koleżankami ${ }^{19}$. Chociaż nie ma powiązań z terroryzmem, to jednak trudno się z godzić z faktem, że jest umiarkowany.

Równie interesujący jest przypadek imama z Colle Val d'Elsa, który twierdzi, że jest umiarkowany, bo chociaż nie rozstaje się z Koranem, to lubi amerykańskie filmy, jest z zawodu fizjoterapeutą i sam rozbiera pacjentki $^{20}$. Nieprzypadkowo deklaruje się jako superumiarkowany, superwielokutlurowy, superzintegrowany i naprawdę nowoczesny. Te określenia jednak już nie pasują do jego żony, która nie chce się integrować: nie mówi po włosku, w telewizji ogląda tylko kanały arabskie i ubiera się tak, jak nakazuje Prorok. Nawet pływa w morzu odziana w ciężką diszdaszę, z twarzą ukrytą za zasłoną, w rękawiczkach, butach, za każdym razem ryzykując, że pójdzie na dno, że zatonie w imię Allacha. Integracja jest pozorna, bo mogą w niej uczestniczyć tylko mężczyźni, bo im Koran tego nie zarania. Problem pojawia się przy integracji kobiet, które musiałyby radykalnie zmienić swoje życie. Na szczęście rzadko wychodzą z domów i można udawać, że muzułmanie próbują się asymilować.

Jednym wielkim przykładem takich pozorów jest Turcja, która obecnie to również kraj muzułmański. Chce ona osiągnąć korzyści gospodarcze z wstąpienia do Unii Europejskiej, jednak nie jest w stanie przełamać mentalności muzułmańskiej społeczeństwa. Fallaci opisuje np. przypadek trzydziestopięcioletniej Cemse Allak, zgwałconej i zapłodnionej przez jakiegoś łajdaka, którą z tego powodu ukamienowała jej własna rodzina.

O. Fallaci, Wywiad z sobą sama. Apokalipsa, s. 186-193.

Ibidem, s. 195.

Ibidem, s. 193. 
Znacznie bardziej szokujące niż sam czyn, jest uzasadnienie szwagierki zabitej, dana angielskiemu dziennikarzowi, który przeprowadzał z nią wywiad: „Co mieliśmy zrobić? Była starą panną i straciła honor. Zgwałcona czy nie, nas także okryła hańbą" ${ }^{21}$. Chociaż kobieta była ofiarą gwałtu, za obcowanie z mężczyzną należy jej się kara, którą wymierza rodzina. Rzecz niepojęta dla - jakby nie patrzeć - jeszcze chrześcijańskiej Europy.

Kulminacją całych rozważań o nieistnieniu umiarkowanego islamu, jest historia dziennikarza, który na łamach „Corriere della Sera” „jako muzułmanin tkwiący jedną nogą na Zachodzie, a drugą w Islamie, z umysłem na Zachodzie i sercem w Islamie, zaprotestował przeciwko edycji Koranu czytanej w środowiskach związanych z Unią Islamskich Gmin i Organizacji we Włoszech. Edycji, w której ujawnia się (używam jego własnych słów) silna ideologiczna wrogość wobec cywilizacji zachodniej"22. Dziennikarz opowiedział się przeciwko tej edycji, ponieważ korzysta ona z Koranu przetłumaczonego ze staro arabskiego, a w konsekwencji pełnego sur, które zalecają kary cielesne, wychwalają Dżihad jako Świętą Wojnę, wysławiają poligamię itp. Takie myślenie nie sprzyja koegzystencji - jego zdaniem - i czyni Świętą Księgę nie do pogodzenia z Państwem Prawa. Oburzenie Fallaci na jego słowa było nie do opisania. Nie można przecież oczyścić tego, co jest z gruntu nieczyste, ocenzurować czegoś, co nie poddaje się cenzurze. Koran przecież pozostanie Koranem bez znaczenia na tłumaczenie, tak samo jak przepaść nie do zasypania pomiędzy teokracją a Państwem Prawa. Dlatego też dobry muzułmanin nie może być umiarkowany.

Podsumowaniem rozważań nad umiarkowanym islamem jest dla Fallaci wypowiedź Adbela Rahmana al-Raszeda, który napisał: „To prawda, że nie wszyscy muzułmanie są terrorystami, ale tak czy inaczej jest też prawdą, że wszyscy terroryści to muzułmanie",23. Współczesny świat bardzo często o tym zapomina, a garstkę muzułman nieterrorystów bierze za reprezentacyjną próbę całego islamu.

Dla Fallaci nie istnieje coś takiego jak umiarkowany islam. To jest tylko hasło obrońców muzułman, którzy starają się nam zamydlić oczy. Skoro Koran nakazuje pewne sposoby zachowań, to albo się je przestrzega i jest się wyznawcą islamu, albo nie. Nie ma czegoś pośrodku. Tym bardziej przekaz świętych ksiąg nie zależy od ich tłumaczenia.

\footnotetext{
Ibidem, s. 221.

Ibidem, s. 197.

Cyt. za: O. Fallaci, Wywiad z sobą samą. Apokalipsa, s. 185.
} 


\section{Ogólne przyzwolenie Zachodu}

Najbardziej uderzające jest, zaprezentowane przez Fallaci, wyjaśnienie obecnej sytuacji i odpowiedź na pytanie, jak doszło do obecnego zalewy Europy ludnością muzułmańską. Jej zdaniem, kryje się za tym „najmroczniejsza zmowa”, „kryje się Europa bankierów, którzy wynaleźli farsę unii Europejskiej, Papieży, którzy wynaleźli bajkę Ekumenizmu, wichrzycieli, którzy wynaleźli łgarstwo Pacyfizmu, hipokrytów, którzy wynaleźli oszustwo Humanitaryzmu. [...] Euroka sprzedająca się jak dziwka sułtanom, kalifom, wezyrom, najemnikom nowego Imperium Osmańskiego. A więc Eurabia"24. Oczywiście Fallaci te zarzuty nie pozostawia bez rozwinięcia. $\mathrm{Na}$ wstępie podkreśla, że ani to określenie, ani poniższe argumenty nie są jej autorstwa, ale Bat Ye'or, specjalistki od islamu i autorki „Islam and Dhimmitude” („Dhimmitude oznacza Poddaństwo Allachowi). W swoich badaniach przedstawia znawczyni sytuację „lekkomyślnej” Europy przełomu lat 60. i 70. Detonatorem zaś całego problemu okazała się konferencja członków OPEC (Arabia Saudyjska, Kuwejt, Iran, Irak, Katar, Abu Dhabi, Bahrajn, Algieria, Libia i tak dalej) w Kuwejcie w dniach 16/17 października 1973 roku, gdzie czterokrotnie podwyższono cenę ropy ${ }^{25}$. Następnie uczestnicy konferencji ogłosili, że każdego miesiąca będą zmniejszać wydobycie o 5\%, nałożone zostało embargo na USA, Danię i Holandię oraz obwieścili, że taką procedurę rozciągną na każdego, kto odrzuci ich żądania polityczne. Domagali się oni wycofana Izraela z okupowanego terytorium, uznanie państwa Palestyńczyków, obecność OWP podczas wszystkich rokowań pokojowych i zastosowanie zasady zawartej w Rezolucji $242 \mathrm{ONZ}^{26}$. Niestety korzyści ekonomiczne były ważniejsze i dziewięć państw EWG poddało się szantażowi. Dziewiętnaście dni później w Brukseli podpisały one dokument, w którym popierały wszystkie postulaty. Rozpoczęto również dialog ze światem arabskim, który oficjalnie nawiązano na Szczycie w Kopenhadze. Następne spotkania posypały się jak lawina. Był to, zdaniem Fallaci, początek końca. Bowiem raz otworzone drzwi do Europy nie udało się już później zamknąć. Najgorsze w tym wszystkim było jednak to, że działo się to na widoku, w świetle dnia i przed kamerami TV. Przystojne zaś zostało wieloma uściskami rąk i bankietami, a mało kto zdawał sobie sprawę, że właśnie wtedy sprzedano Stary Kontynent islamowi.

O. Fallaci, Siła rozumu, s. 151.

Ibidem, s. 155.

26 Oparta na pacyfizmie i korzystna dla krajów arabskich, bo zabrania zdobywania terytoriów na drodze wojny. 
Dlatego też wielokrotnie podkreśla ona, że „Nie ma już Europy. Jest Eurabia” ${ }^{27}$ i wręcz z premedytacją powtarza to słowo. Owa „Eurabia stworzyła sobie bajeczkę wielokulturowego pacyfizmu, zastąpiła określenie „lepszy” przez „odmienny-różnorodny”, zaczęła jazgotać, że nie istnieją lepsze kultury. Nie istnieją lepsze zasady i wartości, są tylko odmienności i różnice postaw" ${ }^{28}$. Nie ma dlatego już miejsca na dyskusję, na wymianę poglądów, bo zniknęła możliwość porównywania ludzkich poczynań. Odmienny nie oznacza przecież gorszy, tylko inny. A skoro jest inny, to nie mamy prawa go oceniać. Jest to oficjalnie otwarcie się podbój przez inne kultury, inne wyznania, które przyjdą ze swoimi zasadami i nas „zakrzyczą".

Zagrożenie islamem jest tym większe, że jeśli nawet kiedyś ktoś dostrzeże zagrożenie, to świat zachodu nie ma jak się bronić, nie ma odpowiednich instytucji, bo na pewno nie są nimi Unia Europejska i ONZ. Fallaci jednoznacznie krytyka obie organizacje: „ONZ to suma wszelkich hipokryzji, koncentrat wszelkiej obłudy. Banda darmozjadów, która w Nowym Jorku pozwala sobie na każde przekroczenie prawa jak długo ma immunitet dyplomatyczny. To mafia..." ${ }^{29}$. Nikt nie wie jak naprawdę funkcjonuje taka instytucja. Natłok osób i stanowisk, które wielokrotnie się dublują i nikt ich nie kontroluje. Ponieważ trudno komukolwiek ogarnąć wszystkie te mafijne relacje, możliwe są przypadki, że fundusze trafiają nie tam gdzie powinny. Jako dowód na potwierdzenie swoich zarzutów, Fallaci podaje przykład „Duńczyka Petera Hansena, komisarza generalnego UNRWA, czyli organizacji humanitarnej zależnej od ONZ, który niedawno przyznał, że finansował zwolenników Hamasu" ${ }^{30}$. Instytucje, które powołane zostały, aby nas chronić, aby dbać o ogólny ład i spokój na świecie, za fasadą utrzymania pokoju, wspierają organizacje, które ten pokój łamią na każdym kroku.

Dla autorki Zachód znajduje się na początku końca, ponieważ jest ślepy, głuchy i ogłupiały. Tragedią wręcz jest to, że trawi go „rak moralny i intelektualny, jego słabość, bojaźliwość. Jego masochizm”" ${ }^{31}$. Europa dla Fallaci jest zastraszona możliwością odcięcia dopływu ropy naftowej i boi się podnieść głowę, powiedzieć „nie” przedstawicielom świata arabskiego. Sama się umartwia i poddaje. A zachłanny, mroczny, żarłoczny Islam

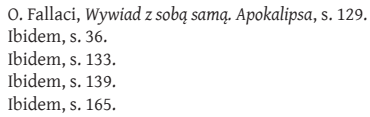


z jego kultem śmierci nie odmówi tak łatwej zdobyczy, która sama wręcz zaprasza wroga.

\section{Czy jest jakaś rada?}

Ten ewidentnie czarny obraz rzeczywistości, który może niejednego przestraszyć, pociąga za sobą pytanie, czy możemy coś na to poradzić. Odpowiedz Fallaci jest tak samo pesymistyczna, jak jej wizja - niestety nie, bo nie ma alternatywy dla demokracji. Choć to ona doprowadziła do tego stanu, to człowiek nie wymyślił jeszcze nic lepszego: „Choć zapychamy sobie usta słowem >>Demokracja<<, dobrze wiemy, że jest ona jak dziurawy okręt. Dobrze wiemy, że stanowi system rozpaczliwie niedoskonały i pod pewnymi względami oszukańczy" ${ }^{\text {"32 }}$. Uzasadniając swoje zdanie, powołuje się ona na Alexisa de Tocqueville'a, który wnikliwie przeanalizował problemy społeczeństwa demokratycznego. „Dwa są, powiada Tocqueville, pojęcia, na których zasadza się demokracja, to pojęcie Równości i pojęcie Wolności" "33. Ludzie jednak bardziej kochają równość. Wolność bowiem wymaga więcej poświęceń, więcej dyscypliny, a prawdą jest, że można być równym także w niewoli. Na domiar złego, ludzie nie rozumieją pojęcia równości. Przez Równość demokracja rozumie równość wobec prawa, a nie równość umysłów i sumień, równość wartości i zasług. Dla Fallaci taki rodzaj równości nie istnieje, ponieważ gdyby istniał, nie byłoby życia. Nie byłoby indywidualności, Olimpiad, meczów piłki nożnej itp. Problem w tym, że demokracja pomaga poprzez wybory głupim zaprzeczać tej oczywistości. W wyborach bowiem liczy się ilość, a nie jakość, każdy może kandydować i zostać wybrany. Dlatego demokracja z zasady odrzuca wartościowanie tak jak poprawność polityczna. Nie ma miejsca na to co jest lepsze, a co gorsze, ważniejsze, że jest czegoś więcej.

Demokracja, ze względu na fundamentalne upodobanie w różnorodności, jest otwartym systemem. A zdaniem Fallaci „Im bardziej społeczeństwo jest otwarte i demokratyczne, tym bardziej narażone na terroryzm. Im bardziej naród jest wolny, tym bardziej naraża się na rzezie...” ${ }^{34}$. Bo to my sami otwieramy granice dla obcokrajowców, czasami nawet sami ich zapraszamy, gdy brakuje rąk do pracy. A tym samym narażamy siebie i własne rodziny na ataki terrorystyczne i zajęcie naszych krajów.

Ibidem, s. 56.

Ibidem.

o. Fallaci, Wściekłość i duma, s. 60. 
W bitwie pomiędzy Europą chrześcijańską a muzułmańską, niestety jesteśmy skazani na porażkę również ze względu na nieświadome niczego młode pokolenie. Autorka jednoznacznie stwierdza: „Tak, przegraliśmy. Bo zamiast uczonych młodych ludzi mamy osły z dyplomami uniwersyteckimi. Zamiast przyszłych przywódców mamy mięczaki w drogich dżinsach i fałszywych rewolucjonistów w kominiarkach. I wiesz co? Może to jest kolejny powód, dla którego nasi muzułmańscy najeźdźcy mają takie łatwe zadanie" ${ }^{35}$. Nie dość, że rodzi się nas mniej, to jeszcze te wychuchane, wypielęgnowane młode osoby nie są gotowe do wzięcia odpowiedzialności za siebie, swoich bliskich, swój kraj. Ważniejsze jest dostatnie życie, dobry samochód i mieszkanie, niż problem imigrantów. Mało kto dzisiaj gotowy jest do poświęceń dla sprawy większej wagi. Młodzi ludzie przestają także samodzielnie myśleć. Płyną jedynie z prądem utartych haseł, powtarzanych schematów dostarczanych im przez media. Nie mają czasu i ochoty, aby w pędzie konsumpcyjnego życia zatrzymać się i samemu zastanowić się nad otaczającym ich światem.

Wielkim błędem Zachodu było zaangażowanie się w problemy Iraku. Oczywiście Fallaci podkreśla swoje zadowolenie z faktu, że Saddam Husajn został usunięty, ale cena za to była zbyt wysoka: „Terroryzm islamski urósł w siłę, martwi zrodzili nowych martwych, nadal ich rodzą i wciąż będą rodzić więcej martwych" ${ }^{\text {"36 }}$. Przewiduje ona, że prędzej czy później, jako odpowiedź na interwencję i śmierć tylu osób, powstanie Islamska Republika Iraku, w której mułłowie i imamowie zmuszają do noszenia burki, kamienują kobiety chodzące do fryzjera, wieszają ludzi na stadionach. Mówi: „Nigdy nie przestanę powtarzać, że demokracji nie można podarować jak tabliczki czekolady. Demokrację trzeba sobie wywalczyć. A żeby ją sobie wywalczyć, trzeba jej pragnąć" ${ }^{37}$. Irakijczycy natomiast nie wiedzą co to jest, dlatego jej nie pragną i nie rozumieją. Ponieważ są muzułmanami wszystko tłumaczą religią, nie potrafią stać się kowalami własnego losu. Teokracja nie uczy rozumować, wybierać i decydować. Muzułmanie mówią o demokracji w islamskim stylu, ale czegoś takiego nie ma. Muzułmanie za bardzo cieszą się z okaleczonych zwłok w amerykańskich mundurach i lubują się w historiach takich, jak obcięcie głowy Paulowi Johnsonowi.

Fallaci nie podaje prostej recepty na to jak uchronić się podstępnym muzułmańskim wrogiem. Współczesna cywilizacja zachodu i jej kon-

\footnotetext{
Ibidem, s. 174 .

O. Fallaci, Wywiad z sobą samą. Apokalipsa, s. 125.

Ibidem, s. 126.
} 
sumpcyjny sposób życia, a także niedoskonała demokracja, nie są w stanie stawić czoła żarłocznemu islamowi. Interwencja zbrojna i otwarta walka także nie rozwiązują problemu, bo nie można nikogo zmusić, aby chciał żyć w inny sposób. Potrzebna jest głębsza przemiana w mentalności wyznawców Mahometa. Biorąc jednak pod uwagę fakt, że teokracja na pierwszym miejscu stawia zawierzenie i poddanie nakazom proroków, ponad samodzielnym rozumowaniem i decydowaniem o własnym losie, może to jednak szybko nie nastąpić.

\section{Zakończenie}

Z przedstawionej powyżej analizy wyłania jest złowieszczy obraz islamu, który jest jak przerażająca bestia w Apokalipsie św. Jana. Tak jak opisane potwory w wizji apostoła zapowiadają koniec świata, tak islam zapowiada koniec starej chrześcijańskiej Europy. Nie będzie to walka zbrojna, zderzenie dwóch armii, a powolne, systematyczne przejmowanie naszej ziemi za pomocą polityki brzucha. Jesteśmy skazani na porażkę, bo wyznawców Mahometa rodzi się więcej niż rdzennych europejczyków. Wykorzystują oni nie tylko swoje kobiety, ale i nasze, a plagą Zachodniej Europy jest konwersja na islam.

Fallaci uważa, że intensywnie propagowana polityka wielokulturowości poniosła porażkę. Muzułmanie nie chcą przyjmować europejskich wartości, nie szanują naszych zasad i tradycji, a także otwarcie wyrażają wrogość wobec zachodniej cywilizacji. Odnosi się wręcz wrażenie, że to my mamy się zasymilować z nimi, bo z dnia na dzień ich żądania rosną. Dialog pomiędzy kulturami jest możliwy tylko wtedy, gdy istnieje jakaś płaszczyzna porozumienia, zbiór wspólnych wartości, którego niestety pomiędzy islamem a chrześcijaństwem nie ma.

Hasła obrońców mniejszości muzułmańskiej, że istnieje umiarkowany islam to jedno wielkie mydlenie oczu. Nawet osoby posiadające pozwolenie na pobyt, mające stałą pracę, zawsze pozostają wyznawcami Mahometa, co ujawnia się w najmniej oczekiwanym momencie. Częściej pozory integracji przejawiają mężczyźni, bo dużo więcej im wolno niż kobietom. Płeć piękna pozostaje zaś uwięziona w czadorach, nikabach i ścianach własnego domu. Bardzo często nawet nie uczą się języka kraju przyjmującego, bo nawet nie miałyby gdzie go używać.

Najgorsze jest, że politycy europejscy w imię politycznej poprawności i wielokulturowości tolerują praktyki ewidentnie sprzeczne z wartościami europejskimi, np. dyskryminację kobiet - żon muzułmanów. Nazywa się je eufemistycznie odmiennymi wzorcami kulturowymi. Unia 
Europejska na oczach tysięcy ludzi sprzedała swoje terytorium za ropę naftową. Słaba i bojaźliwa Europa otworzyła drzwi dla inwazji islamskiej i nie już siły ich zamknąć. Jednocześnie zachodnie elity intelektualne, zwłaszcza lewicowe, są otwarcie antychrześcijańskie i równocześnie otwarcie pro islamskie. Elity stosują politykę przemilczania oraz ignorowania zagrożenia.

Pesymistyczny jest wniosek Fallaci, że nie ma sposobu na poradzenie sobie $\mathrm{z}$ islamskim wrogiem i ona sama nie daje odpowiedzi co należałoby zrobić. Dlaczego jednak skazani jesteśmy na przegraną? odpowiedź kryje się w obecnej sytuacji Europy i jej ewidentnym kryzysie, na który składają się dwa elementy: postępująca laicyzacja i malejący przyrost naturalny. Chrześcijaństwo intensywnie traci swoich wyznawców, a określenie „wierzący, ale nie praktykujący” coraz częściej można usłyszeć. Społeczeństwa odcinając się od wiary, tracą więzi ze swoją tradycją i wartościami historycznymi, a tym samym narody tracą swoją tożsamość. Po drugie, rdzenni Europejczycy regularnie wymierają. Kobiety na Starym Kontynencie rodzą za mało dzieci, aby następowała prosta wymiana pokoleń. Aby utrzymać rynek pracy na stałym poziomie, potrzebni będą imigranci, a to zapotrzebowanie doskonale wypełnia ludność muzułmańska, której ciągle przybywa w Europie. Nasza kultura wymiera, a jej miejsce zastępuje taka, która - chociaż na niższym etapie rozwoju - to lepiej sobie poradziła ze współczesnymi problemami. Jesteśmy nad przepaścią, ale możemy jeszcze powstrzymać upadek. Trzeba jednak uświadomić sobie zagrożenie i zmienić podejście do muzułmańskich imigrantów.

Fallaci prezentuje obecną sytuację w Europie w kategoriach konfliktu. Na starym kontynencie rywalizują ze sobą cywilizacja zachodnia z chrześcijańskimi korzeniami oraz cywilizacja islamska. Ze względu na różnice kulturowe i brak wspólnych wartości nie możliwe jest ich współistnienie, a konflikt wręcz nieunikniony. Ze względu na kryzys wartości i ujemny przyrost naturalny, Europa systematycznie traci swoje wpływy, których miejsce zajmuje kultura muzułmańska. Zarówno krytycy, jak i zwolennicy Fallaci, porównują jej poglądy do zderzenia cywilizacji Samuela Huntingtona, chociaż ci pierwsi uważają, że nie dorównuje ona oryginałowi i deprecjonują jej znaczenie. Podobnie jak Huntington, autorka bardzo jednoznacznie dokonuje podziału pomiędzy cywilizacjami i cechami im przypisanymi, aby potwierdzić swoją teorię konfliktu. Pokojowe współistnienie było tylko okresem przejściowym. Nie uwzględnia ona wpływu globalizacji na zamazywanie się różnic kulturowych, a cywilizacje są dla niej jednolite. 
Huntington przewidywał, że kolejna wojna światowa będzie się toczyć najprawdopodobniej między Chinami a Zachodem lub między Zachodem a islamem. Krytycy Huntingtona zarzucali mu, że jego koncepcja jest próbom usankcjonowania agresji Zachodu. Fallaci w tej kwestii się różni, bo chociaż jest zadowolona z usunięcia Saddama Husajna, to jednak uważa, że nie można narzucać demokracji i europejskich wartości siłą. Trzeba do nich dojrzeć i samemu je wywalczyć, co tym samym zakłada ich wyższość. Nie uważa ona także, aby otwarty konflikt zbrojny był konieczny - chociaż sama przyznaje, że początkowo brała to pod uwagę. Jest ona przekonana, że przejęcie cywilizacji zachodniej przez islam nastąpi drogą pokojową za pomocą wojny demograficznej i przewagi liczebnej.

Ze względu na pełne podróży i interesujące życie Oriany Fallaci, jej książki bogate są w przykłady i historie, których doświadczyła autorka. Dzięki temu czytelnik ma wrażenie, że uzyskane informacje są z pierwszej ręki, a tym samym są bardziej autentyczne i wiarygodne. Jednak niektórzy znawcy jej twórczości twierdzą, że fakty w jej książkach zostały w przekonywujący sposób "nadmuchane" i zmitologizowane. Jej biograf Santo Aricó uważa, że Fallaci jest swoją własną supergwiazdą, a światła muszą być skierowane na nią ${ }^{38}$. Nie ma co ukrywać, że chociaż pisze o problemach współczesnego świata, to główną bohaterką jej książek jest właśnie ona sama.

Fallaci ma wielką zdolność do emocjonalnego wpływania na czytelnika. Umiejętnie dobiera argumenty na potwierdzenie swoich tez, przedstawiając tylko jedną stronę medalu. Nie daje ona całej palety postaw wyznawców islamu, co ze względu na uczuciowe podejście, nie jest widoczne na pierwszy rzut oka. Tworzy ona obraz przeciętnego muzułmanina oraz przeciętnego europejczyka, którzy może stanowią większość każdej zbiorowości, to jednak nie wypełniają jej w $100 \%$.

Daniel Pipes uważa Fallaci za bojowniczkę o pokój, wolność i demokrację $^{39}$. To określenie tkwi u podłoża popularności autorki, bo Europa cierpi na kryzys tych wartości. Chociaż możliwe, że cierpi ona na kryzys wartości jako takich, bo czy na naszym kontynencie funkcjonują jeszcze jakiekolwiek wartości? Przecież nikt dzisiaj się nie odważy jednoznacznie określić co jest dobre, a co złe, a wszystko jest zindywidualizowane do granic możliwości. Nie ma prawd obiektywnych, bo wszystko jest względne,

38 OrianaFallaci.Wściekła, http://www.wysokieobcasy.pl/wysokie-obcasy/1,96856,619367. html [dostęp: 29.03.2010 r.].

39 D. Pipes, „Racja Oriany Fallaci, http://pl.danielpipes.org/3430/racja-oriany-fallaci [dostęp: 29.03.2010 r.]. 
a mnogość prawd indywidualnych nakazuje nam pozostawać z nimi w zaciszu własnego domu. Skoro jest coraz mniej autorytetów, a kanon wartości przestał istnieć, to jednostka może czuć się zagubiona i łatwo ulegnie komuś, kto odważy się określić co jest białe, a co czarne.

Europa ma problem wartości i tożsamości. Imigranci zajmują miejsca pracy, co coraz mniej podoba się rdzennym mieszkańcom. Oriana Fallaci jest papierkiem lakmusowym obecnej sytuacji Europy, która będąc na rozdrożu rozpaczliwie szuka wyjścia z sytuacji. Zapewne wiele można zarzucić jej pracom, ale warto się zastanowić, czy jej apokaliptyczna wizja ma możliwość się ziścić.

Jean Raspail 20 lat temu nazywany był faszystą, rasistą, reakcjonistą z powodu „Obozu świętych”, a dzisiaj ta książka jest we Francji swego rodzaju klasyką. Dawni jego krytycy i prześmiewcy, dzisiaj odwołują swoje słowa, bo wizja autora z każdym dniem bardziej się urzeczywistnia. Fallaci również przez wielu wytykana i wyszydzania, konsekwentnie szła pod prąd poprawności politycznej i otwarcie przedstawiała swoje zdanie. Od wydania pierwszej pracy na temat islamu nie minęło jeszcze 20 lat. Czy czeka ją taki sam los jak Raspaila? 


\section{Abstract}

Oriana Fallaci is one of the most controversial character of early twentyfirst century. Journalist and writer, veteran of many wars, became famous with the aggressive and passionate interviews with world leaders - from the Ayatollah Khomeini to Lech Walesa. After years of silence, an Italian writer announced on the pages of "Corriere della Sera" article "The Rage and the Pride", in which attacks Islam and calls for the defense of western civilization. Introduced on 29 September 2001 and was the beginning of an intensive campaign against Islam. This article gave rise to the first work devoted to issues of contemporary Islam with the same title. Its quite a spectacular return to the scientific discourse, Fallaci explains that there are moments in life when silence becomes a sin, and the speech is imperative. Its message for modern civilization and Western Europe continued in the following books: "The Force of Reason" and "Interview with my self. Apocalypse. These three studies describe and analyze Islam, which for Fallaci is a great threat to the Christian Old Continent. Openly, bluntly presents an apocalyptic vision of a Europe which is happening in her eyes.

Opinions about her and her work are different. Some love her and praise, others criticize and accuse of racism and promote hostility toward the Arabs. Also, critics are divided on the artistic value of her work. For sure, however, caused much confusion in the modern world with their original ideas and they are worth to discuss. Oriana Fallaci believes that she flows upstream and dares to say things, which are thrown out of the official discourse. In her view, this kind of taboo is Islam and its followers.

Fallaci presents the current situation in Europe in terms of conflict. On the old continent compete Western civilization with Islamic civilization. Due to cultural differences and lack of shared values is not possible to coexistence and conflict is almost inevitable. In connection with the crisis of values and the negative natural increase, Europe is steadily losing its influence, which place is taken by the Muslim culture. Fallaci believes that the policy of multiculturalism promoted heavily defeated. Muslims do not want to accept European values, do not respect our rules and traditions, and openly express their hostility toward Western civilization. The password of the defenders of the Muslim minority, that there is a moderate Islam is one big bluff. 